\title{
PENGARUH MODEL PEMBELAJARAN PROBING PROMPTING TERHADAP AKTIVITAS DAN HASIL BELAJAR SISWA PADA MATA PELAJARAN PPKn KELAS VII DI MTS HIDAYATULLAH MATARAM TAHUN PELAJARAN 2017/2018
}

\author{
Supriyadi ${ }^{1}$, Komang Sundara ${ }^{2}$
}

\author{
${ }^{1}$ Pendidikan Pancasila dan Kewarganegaraan, Universitas Muhammadiyah Mataram, supriyadi78@gmail.com \\ ${ }^{2}$ Pendidikan Pancasila dan Kewarganegaraan, Universitas Muhammadiyah Mataram, komangsundara@gmail.com
}

INFO ARTIKEL
Riwayat Artikel:
Diterima: $\quad$ 19-Februari-
2018
Disetujui: 23-Maret-2018

Kata Kunci:

Probing Promting

Aktivitas belajar

Hasil belajar

\section{A. LATAR BELAKANG}

Guru dalam proses pembelajaran memegang peran yang sangat penting, guru tidak hanya berperan sebagai model atau teladan bagi siswa yang diajarnya tetapi juga sebagai pengelola pembelajaran (manager of learning)[1]. Guru PPKn harus menguasai berbagai macam metode dan teknik pembelajaran PPKn. Ia harus mampu menciptakan suasana belajar yang nyaman dan

\begin{abstract}
Abstrak: Pendidikan merupakan suatu usaha yang mencetak seseorang menjadi generasi yang berkualitas dan memiliki daya saing. Tujuan dari penelitian ini adalah untuk mengetahui aktivitas dan hasil belajar PPKn siswa kelas VII MTs Hidayatullah Mataram tahun pelajaran 2017/2018 melalui model pembelajaran Probing prompting. Jenis penelitian ini adalah penelitian tindakan kelas, jumlah subyek penelitian sebanyak 23 siswa. Prosedur penelitian terdiri dari empat tahap yaitu: tahap perencanaan, tahap pelaksanaan, tahap pengamatan dan tahap refleksi. Metode pengumpulan data yang digunakan yakni pengamatan, tes, non tes dan dokumentasi. Jenis data yang dipergunakan dalam penelitian adalah kuantitatif yang berupa perhitungan nilai rata-rata, jumlah, maupun presentase dari hasil belajar. dan kualitatif yaitu hasil pengamatan yang berpedoman pada lembar pengamatan aktivitas siswa. Berdasarkan hasil penelitian dan hasil analisis data yang dilakukan, maka dapat menarik disimpulkan bahwa terjadi peningkatan ketuntasan klasikal siswa yaitu sebesar $80 \%$. Jadi dapat disimpulkan bahwa implementasi model pembelajaran Probing prompting dapat meningkatkan aktivitas dan hasil belajar siswa PPKn kelas VII di Mts Hidayatullah Mataram, guru disarankan untuk menggunakan metode maupun model pembelajaran yang menarik minat dan perhatian siswa dalam belajar kemudian dari kekurangan selama proses pembelajaran dengan menggunakan model Probing prompting diharapkan untuk diperbaiki lagi.
\end{abstract}

\begin{abstract}
Education is a business that prints someone into a generation of quality and competitiveness. The purpose of this study was to determine the activities and learning outcomes of PPKn VII graders of MTs Hidayatullah Mataram in the 2017/2018 academic year through the Probing prompting learning model. This type of research is classroom action research, the number of research subjects is 23 students. The research procedure consists of four stages, namely: the planning stage, the implementation phase, the observation stage and the reflection stage. Data collection methods used are observation, tests, non-tests and documentation. The type of data used in the study is quantitative in the form of calculating the average value, number, and percentage of learning outcomes. and qualitative, namely the results of observations guided by student activity observation sheets. Based on the results of the research and the results of the data analysis carried out, it can be interesting to conclude that there was an increase in the classical completeness of students which was equal to $80 \%$. So it can be concluded that the implementation of the Probing prompting learning model can improve the activities and learning outcomes of class VII PPKn students at Hidayatullah Mts Mataram, teachers are advised to use learning methods and models that attract students' interest and attention in learning later from deficiencies during the learning process using the Probing model prompting is expected to be fixed again.
\end{abstract}

menyenangkan agar proses belajar mengajar dapat berlangsung dengan cepat dan baik. Selera humor guru sangat penting dalam proses pembelajaran, tetapi jangan sampai mengurangi inti pembelajaran PPKn itu sendiri.

Salah satu permasalahan dalam bidang pendidikan, khususnya mata pelajaran pendidikan Pancasila dan kewarganegaraan adalah sulitnya pemahaman siswa dalam menerima materi yang disampaikan guru pada 
proses pembelajaran, Persoalan ini di alami siswa kelas VII di MTs Hidayatullah Mataram khususnya pada mata pelajaran Pendidikan Pancasila dan Kewarganegaraan.

Berdasarkan hasil wawancara awal dengan guru PPKn kelas VII MTs Hidayatullah Mataram terlihat bahwa: 1) Masih banyak siswa yang tidak memperhatikan guru dalam menjelaskan materi pembelajaran, 2) Sering kali ketika siswa diberi kesempatan untuk bertanya oleh gurunya siswa hanya berdiam, sementara siswa belum tentu memahami materi yang disampaikan guru, 3) siswa masih takut menjawab pertanyaan yang diajukan oleh guru, sehingga menyebabkan daya berpikir kritis siswa terhadap materi yang diajarkan oleh guru masih rendah, 4) pembelajaran yang dilakukan oleh guru masih dominan menggunakan metode ceramah, tidak memanfaatkan berbagai strategi dan model-model pembelajaran yang lain, Sehingga prestasi belajar siswa belum bisa mencapai target yang diharapkan, masih banyak siswa yang nilai kriteria kelulusannya (KKM) di bawah standar, dari 23 siswa tercatat 20 orang siswa yang nilai kriteria kelulusannya (KKM) di bawah standar.

Salah satu cara yang dapat dilakukan untuk meningkatkan prestasi belajar siswa dalam proses pembelajaran PPKn adalah dengan menerapkan model pembelajaran Probing Prompting. Penerapan model pembelajaran Probing Prompting adalah salah satu inovasi yang dilakukan oleh peneliti untuk dapat meningkatkan keaktiktifan para peserta didik agar membuat suasana di dalam kelas lebih aktif.

Pembelajaran Probing Prompting adalah pembelajaran dengan cara guru menyajikan serangkaian pertanyaan yang sifatnya menuntun dan menggali sehingga terjadi proses berpikir yang mengaitkan pengetahuan tiap siswa dan pengalamannya dengan pengetahuan baru yang sedang dipelajari (Suherman, 2008:6).

Kemungkinan akan terjadi suasana tegang pada siswa siswa, namun demikian bisa dibiasakan untuk mengurangi kondisi tersebut, guru hendaknya memberi serangkaian pertanyaan disertai dengan wajah ramah, suara menyejukkan, dan nada yang lembut. Ada canda, senyum dan tertawa sehingga menjadi nyaman.

Oleh sebab itu, dengan menerapkan model pembelajaran Probing Prompting diharapkan dapat meningkatkan prestasi belajar siswa, setelah kegiatan belajar mengajar berlangsung.

Pembelajaran Probing Prompting adalah pembelajaran dengan cara guru menyajikan serangkaian pertanyaan yang sifatnya menuntun dan menggali sehingga terjadi proses berpikir yang mengaitkan pengetahuan tiap siswa dan pengalamannya dengan pengetahuan baru yang sedang dipelajari[2].

Selanjutnya siswa mengkonstruksi konsep-prinsip dan aturan menjadi pengetahuan baru, dengan demikian pengetahuan baru tidak diberitahukan. Model
Pembelajaran Probing Prompting sangat erat kaitannya dengan pertanyaan. Pertanyaan-pertanyaan yang dilontarkan pada saat pembelajaran ini disebut (probing question). Probing question adalah pertanyaan yang bersifat menggali untuk mendapatkan jawaban lebih lanjut dari siswa yang bermaksud untuk mengembangkan kualitas jawaban, sehingga jawaban berikutnya lebih jelas, akurat serta beralasan[2].

Probing question ini dapat memotivasi siswa untuk memahami lebih mendalam suatu masalah sehingga mencapai suatu jawaban yang dituju. Proses pencarian dan penemuan jawaban atas masalah tersebut peserta didik berusaha menghubungkan pengetahuan dan pengalaman yang telah dimilikinya dengan pertanyaan yang akan dijawabnya. Dengan model pembelajaran ini proses tanya jawab dilakukan dengan menunjuk siswa secara acak sehingga setiap siswa mau tidak mau harus berpartisipasi aktif, siswa tidak bisa menghindar dari proses pembelajaran, setiap saat ia bisa dilibatkan dalam proses tanya jawab. Berdasarkan penelitian bahwa proses Probing dapat mengaktifkan siswa dalam belajar yang penuh tantangan, membutuhkan konsentrasi dan keaktifan[3].

Aktifitas belajar adalah serangkain kegiatan fisik atau jasmani maupun mental yang saling berkaitan sehingga tercipta belajar yang optimal[4]. Dalam aktifitas belajar ini peserta didik haruslah aktif dalam mengikuti proses belajar dan juga mentaati apa yang menjadi peraturan sekolah dengan menerapkan prilaku yang baik dan sikap sosial yang tinggi kepada guru dan teman teman.

Istilah hasil belajar berasal dari bahasa Belanda "Prestatie", dalam bahasa Indonesia menjadi prestasi yang berarti hasil usaha. Hasil belajar adalah hasil yang telah dicapai siswa dalam bentuk penguasaan dan penilaian terhadap tingkah laku, kecakapan dasar dan nila-nilai ilmu pengetahuan[5].

Hasil belajar adalah kemampuan yang dimiliki peserta didik setelah menerima pengalaman belajarnya[6]. Hasil belajar pada hakikatnya ialah perubahan tingkah laku pada pengertian yang luas mencangkup ranah kognotif, afektif, dan psikomotorik.

\section{B. METODE PENELITIAN}

1. Rancangan Penelitian

Penelitian ini adalah penelitian tindakan kelas, Penelitian Tindakan Kelas pada dasarnya bertujuan untuk meningkatkan dan memperbaiki kegiatan pendidikan di sekolah dan kegiatan pembelajaran di kelas

Penelitian tindakan kelas merupakan suatu pencermatan terhadap kegiatan yang sengaja dimunculkan, dan terjadi dalam sebuah kelas[7]. Penelitian tindakan kelas pada hakikatnya berupa rangakaian kegiatan yang terdiri dari empat langkah, yaitu perencanaan, pelaksanaan, observasi/evaluasi, dan refleksi. 
Penelitian ini akan menggunakan model penelitian tindakan kelas dengan model pembelajaran Probing prompting yang dapat dijadikan cara untuk melakukan pembelajaran. Penelitian tindakan kelas ini menggunakan asas kolaborasi (kerja sama) Dalam hal ini peneliti dan guru secara bersama-sama membuat rancangan penelitian, selanjutnya guru itulah yang mengajar didalam kelas dengan menggunakan model pembelajaran

Probing prompting. dengan tujuan untuk memperbaiki strategi atau model pembelajaran untuk meningkatkan aktivitas dan hasil belajar siswa sedangkan peran peneliti adalah melakukan pengamatan selama jalannya proses belajar mengajar didalam kelas untuk mengetahui aktivitas dan hasil belajar siswa, setelah proses belajar mengajar selesai peneliti dan guru merefleksi kekurangan-kekurangan selama proses belajar mengajar untuk diperbaiki pada pertemuan berikutnya.

\section{Subjek dan Objek Penelitian}

Subjek penelitian adalah seseorang atau sesuatu mengenai yang mengenainya ingin diperoleh keterangan[8]. Subjek penelitian sebagai benda, hal atau orang tempat data untuk variabel penelitian melekat, dan yang dipermasalahkan[7]. Subjek dalam penelitian ini adalah siswa kelas VII yang terdiri dari 23 siswa.

Objek penelitian adalah sifat keadaan dari suatu benda, orang, atau yang menjadi pusat perhatian dan sasaran penelitian. Sifat keadaan dimaksud bisa berupa sifat, kuantitas, dan kualitas yang bisa berupa perilaku, kegiatan, pendapat, pandangan penilaian, sikap prokontra, simpati-antipati, keadaan batin, dan bisa juga berupa proses[7]. Objek dalam penelitian ini adalah model pembelajaran Probing Prompting untuk meningkatkan aktivitas dan hasil belajar siswa pada mata pelajaran Ppkn kelas VII di Mts Hidayatullah Mataram tahun pelajaran2017/2018.

\section{Lokasi Penelitian}

Lokasi penelitian ini adalah MTs Hidayatullah Mataram Kelas VII, dimana penelitian dilaksanakan pada semester Genap (dua). Adapun alasan peneliti melakukan penelitian di MTs Hidayatullah Mataram ini adalah MTS Hidayatullah Mataram belum pernah menerapkan model pembelajaran Probing Prompting.

\section{Prosedur Penelitian}

Penelitian ini menggunakan proses tindakan yang dilaksanakan menggunakan siklus. PTK pada hakikatnya berupa rangkaian kegiatan yang terdiri dari empat langkah, yaitu perencanaan, pelaksanaan, pengamatan dan refleksi[7].

Prosedur penelitian merupakan langkah-langkah operasional baik yang berkaitan dengan perencanaan, pelaksanaan, pengamatan, maupun refleksi. Prosedur penelitian yang digunakan dalam penelitian ini menggunakan konsep penelitian tindakan kelas (PTK). Adapun secara jelas dapat dilihat di bawah ini a. Perencanaan
Kegiatan yang dilakukan antara lain:

1) Menyiapkan bahan ajar yaitu materi yang akan diajarkan tentang sistem pembagian kekuasaan negara republik indonesia.

2) Menyusun RPP sesuai dengan model pembelajaran (Probing prompting)

3) Menyusun soal tes yaitu yaitu instrumen untuk mengetahui hasil belajar siswa, yang terdiri dari soal pilihan ganda.

4) Menyusun pedoman pengamatan yaitu untuk melihat aktivitas belajar siswa ketika diterapkan model pembelajaran Probing prompting.

b. Pelaksanaan Tindakan

Kegiatan yang dilaksanakan pada tahap ini adalah:

1) Melaksanakan pembelajaran dengan berpedoman pada skenario pembelajaran yang sudah dibuat.

2) Pelaksanaan pengamatan selama berlangsungnya proses pembelajaran oleh pengamat.

c. Pengamatan

Pelaksanaan pengamatan dilakukan oleh pengamat secara kontinu setiap kali pembelajaran berlangsung dalam pelaksanaan tindakan dengan mengamati aktivitas siswa pada pembelajaran PPKn dengan menggunakan model pembelajaran Probing prompting dalam hal ini yang bertindak sebagai pengamat adalah peneliti dan guru mata pelajaran PPKn yang mengajar pada kelas tempat penelitian.

d. Refleksi

Refleksi dilakukan setiap akhir siklus, pada tahap ini peneliti bersama guru yang bertindak sebagai observer mengkaji hasil yang diperoleh dari pemberian tindakan pada setiap siklus. Kegiatan yang dilakukan pada tahap ini antara lain:

1) Mengkaji kekurangan-kekurangan atau hambatanhambatan selama berlangsungnya proses pembelajaran.

2) Melakukan langkah-langkah perbaikan untuk melaksanakan proses pembelajaran pada siklus berikutnya.

5. Tehnik Pengumpulan Data

Adapun metode pengumpulan data yang digunakan oleh peneliti dalam melakukan penelitian ini antara lain.

a. Tehnik dokumentasi

b. Tehnik Tes

c. Tehnik Non tes

d. Instrumen Penelitian

Instrument adalah alat pada waktu penelitian dengan menggunakan sesuatu metode[7]. Sedangkan pendapat lain mengatakan instrumen penelitian[9] adalah alat bantu yang dipilih dan digunakan peneliti dalam kegiatan pengumpulan data.

\section{HASIL DAN PEMBAHASAN}

\section{Penyajian Data}

a. Tahap perencanaan (Siklus 1)

Pada tahap ini dilakukan beberapa perencanaan sebelum siklus-siklus dilaksanakan. Perencanaan ini meliputi: (1)menyiapkan bahan ajar yaitu materi yang 
akan diajarkan tentang sistem pembagian kekuasaan negara republik indonesia. (2) menyusun RPP sesuai Model pembelajaran Probing prompting dalam meningkatkan aktivitas dan hasil belajar siswa. (3) menyusun soal tes yaitu instrumen untuk mengetahui Hasil belajar siswa, yang terdiri dari soal pilihan ganda (4) membuat pedoman pengamatan yaitu untuk melihat aktivitas belajar siswa ketika diterapkan model pembelajaran Probing prompting. b. Tahap pelaksanaan (Siklus 1)

Kegiatan yang dilaksanakan pada tahap ini adalah melaksanakan kegiatan pembelajaran dikelas sesuai dengan scenario pembelajaran yang telah direncanakan melalui model pembelajaran Probing prompting.

c. Tahap Pengamatan

Untuk mengetahui aktivitas siswa pada siklus 1, dilakukan pengamatan oleh peneliti. Dari hasil pengamatan aktivitas siswa diperoleh data sebagai berikut:

Tabel 1. Aktivitas siswa

\begin{tabular}{|c|c|}
\hline Keterangan & Skor \\
\hline Jumlah siswa & 23 \\
\hline Nilai total & 790 \\
\hline Nilai rata-rata & 34,34 \\
\hline Kategori & Sangat Kurang \\
\hline
\end{tabular}

Data tentang aktivitas belajar siswa diperoleh dengan mengamati selama proses belajar mengajar berlangsung, yang bertujuan untuk mengetahui adanya peningkatan aktivitas siswa setelah menggunakan model pembelajaran Probing prompting. Dari hasil pengamatan aktivitas siswa menggunakan model pembelajaran Probing prompting. prosentase sebesar 34,34\% kategori sangat kurang. Dapat dilihat bahwa kegiatan siswa yang berjalan dengan baik adalah kesiapan dan antusias siswa dalam mengikuti kegiatan pembelajaran. Selain itu terdapat pula kekurangan pada pelaksanaan pembelajaran, .

Pada siklus 2 materi yang diajarkan mengenai Kerjasama dalam berbagai kehidupan.Pada prinsipnya model pembelajaran yang digunakan pada siklus 2 sama dengan siklus 1, namun pada siklus 2 dilakukan perbaikan-perbaikan berdasarkan siklus 1. Langkahlangkah penelitian yang digunakan sama dengan tindakan pada siklus 1 .

Untuk mengetahui aktivitasl belajar siswa siklus II, dilakukan pengamatan oleh peneliti. Dari hasil pengamatan Aktivitas belajar siswa diperoleh data sebagai berikut:

Tabel 2: Aktivitas Belajar

\begin{tabular}{|c|c|}
\hline Keterangan & Skor \\
\hline Jumlah siswa & 23 \\
\hline Nilai total & 1906 \\
\hline Nilai rata-rata & 82,86 \\
\hline Kategori & Baik \\
\hline
\end{tabular}

Data tentang aktivitas belajar siswa diperoleh dengan mengamati selama proses belajar mengajar berlangsung, yang bertujuan untuk mengetahui adanya peningkatan sikap sosial setelah menggunakan model pembelajaran Probing prompting. Dari hasil pengamatan aktivitas belajar siswa menggunakan model pembelajaran Probing prompting prosentase sebesar $82,86 \%$ kategori baik. Dapat dilihat bahwa kegiatan siswa yang berjalan dengan baik adalah kesiapan dan antusias siswa dalam mengikuti kegiatan pembelajaran.

\section{Pembahasan}

Penelitian tindakan kelas ini bertujuan untuk meningkatkan Aktivitas dan hasil belajar siswa melalui model pembelajaran Probing prompting pada mata pelajaran PPKn kelas VII Di MTs Hidayatullah Mataram.

Peningkatan Aktivitas belajar dari siklus 1, Pertemuan 1 dan pertemuan 2, siklus 2 dan terjadi karena guru menggunakan model pembelajaran Probing prompting yang didalam model pembelajaran tersebut memberikan penekanan kepada siswa untuk saling tanya jawab antara guru dan siswa. Penggunaan model pembelajaran Probing prompting membuat siswa semakin aktif dan lebih mengoptimalkan potensi yang ada didalam dirinya.

Siswa dapat menggunakan gaya belajar yang dimiliki dalam proses pembelajaran. Karena pada model ini siswa yang akan menentukan bagaimana cara siswa belajar. Dari penjelasan diatas peneliti dapat menyimpulkan bahwa model pembelajaran Probing prompting adalah model yang menjadikan siswa menjadi aktif dalam pembelajaran. Karena dalam model ini siswa diajak untuk saling Tanya jawab dengan guru

Begitupun juga dengan peningkatan hasil belajar dari siklus 1 pertemuan 1, siklus 1 pertemuan 2, siklus 2 yang terjadi karena Aktivits belajar yang sudah dimilki siswa selama proses pembelajaran berlangsung melalui model Probing prompting yang guru dapat dilihat dari semangat siswa dalam proses pembelajaran berlangsung.

Sejalan dengan hal tersebut dapat diartikan pula bahwa model pembelajaran Probing prompting berhasil meningkatkan Aktivitas dan hasil belajar siswa pada mata pelajaran PPKn. Sesuai hasil penelitian sudarti bahwa "Proses Probing dapat mengaktifkan siswa dalam belajar yang penuh tantangan, sebab ia menuntut konsentrasi dan keaktifan"[3]. Tujuan pada penelitian yang telah ditetapkan pada penelitian ini adalah meningkatkan aktivitas dan hasil belajar siswa pada kegiatan pembelajaran Ppkn. Model pembelajaran Probing Prompting juga merupakan upaya untuk memicu adanya motivasi dan semangat belajar serta pemahaman siswa terhadap pengetahuan yang telah yang telah dipelajari.

Berdasarkan hasil analisis dan pengamatan seperti yang diterangkan di atas baik siklus 1 pertemuan 1, siklus 1 pertemuan 2, dan siklus 2 dapat dikemukakan bahwa aktivitas dan hasil belajar siswa pada mata pelajaran PPKn mengalami peningkatan yang berarti dengan model pembelajaran Probing prompting dalam proses pembelajaran. Karena membentuk demokrasi dan peran aktif siswa dalam menentukan apa yang harus dipelajari dan bagaimana cara mempelajarinya serta membantu siswa memahami konsep-konsep yang sulit sehingga mampu menumbuhkan kemampuan kerja siswa dan berpikir kritis.

Hal ini sesuai dengan temuan peneliti saat peneliti melakukan kegiatan penelitian, anatara lain:

a. Model Probing prompting dalam kegiatan pembelajaran PPKn mampu meningkatkan aktivitas dan hasil belajar siswa. 
b. Pada saat kegiatan pembelajaran berlangsung siswa lebih terlihat antusias, siswa lebih termotivasi dalam mengikuti mata pelajaran PPKn.

c. Penggunaan model Probing prompting dapat meningkatkan pemahaman siswa pada materi, karena model Probing prompting lebih ditekankan agar siswa bias melakukan Tanya jawab.

\section{SIMPULAN DAN SARAN}

Berdasarkan hasil penelitian dan hasil analisis data yang dilakukan, maka dapat di simpulkan bahwa: (1) penerapan model pembelajaran Probing prompting dapat meningkatkan Aktivitas belajar siswa, berdasarkan hasil pengamatan, presentase aktivitas pada siklus I pertemuan I adalah $34,34 \%$ dengan kategori sangat kurang, siklus I pertemuan 2 (dua) $72,39 \%$ dengan kategori cukup dan siklus II 82,86\% dengan kategori baik. (2) penerapan model pembelajaran Probing prompting pada pembelajaran PPKn dapat meningkatkan hasil belajar siswa. Hal ini menunjukkan presntase ketuntasan hasil belajar siswa secara klasikal pada siklus I sebesar $51,73 \%$, siklus II $80,43 \%$ mengalami peningkatan.

Hal ini menunjukkan adanya peningkatan Aktivitas dan hasil belajar siswa dengan mengunakan model pembelajaran Probing prompting pada siswa PPKn kelas VII Mts Hidayatullah mataram Tahun Pelajaran 2017/2018.

Peneliti menyampaikan beberapan saran, diantaranya : Bagi Guru, Guru disarankan menggunakan metode pembelajaran maupun model pembelajaran bervariasi dan serta menarik minat perhatian siswa dalam belajar. Sebaiknya guru menghindari penggunaan metode maupun model pembelajaran yang monoton dalam jangka waktu tertentu yang berdampak kurangnya minat dan perhatian siswa dalam mengikuti pelajaran. Selain itu, guru disarankan dapat menciptakan suasana kelas kondusif yang aktif, kreatif, efektif, dan menyenangkan, agar tujuan pembelajaran dapat tercapai. Guru juga harus dapat menanamkan dan membina sikap positif dan demokratis antara siswa, agar siswa tidak canggung mengikuti pelajaran dan dengan mudah bekerja sama dan berinteraksi dengan teman-temannya terutama dalam memecahkan masalah-masalah yang dijumpai siswa dalam belajar.

Bagi siswa, siswa sebaiknya dapat bekerja sama dengan teman-temannya tanpa memandang status sosial maupun ekonominya. Dalam bekerja sama, siswa harus bisa menghargai pendapat temannya yang berbeda darinya. Selain itu juga, siswa harus tolong menolong dengan teman-temannya ketika menghadapi permasalahan dalam belajar. Siswa hendaknya tidak mengandalkan kemampuan akademik temannya yang lebih darinya ketika diskusi, siswa harus terlibat aktif dalam proses belajar mengajar, siswa disarankan berani untuk mengemukakan pendapat, berani bertanya kepada guru, berani tampil didepan kelas, dan memupuk rasa percaya diri yang kuat dalam belajar.
Bagi Sekolah, Penelitian menyarankan agar sekolah senantiasa memotivasi guru-guru untuk menerapkan metode maupun model pembelajaran yang lebih menarik minat dan perhatian siswa dalam belajar.

\section{UCAPAN TERIMA KASIH}

Penulis mengucapkan terima kasih kepada editor yang senantiasa memberikan saran dan masukan kepada penulis sehingga artikel ilimiah ini selesai dengan baik.

\section{DAFTAR RUJUKAN}

[1] W. Sanjaya, Perencanaan dan desain sistem pembelajaran. Kencana, 2015.

[2] S. Erman, "Model Belajar dan Pembelajaran Berorientasi Kompetensi Siswa," Educare, vol. 5, no. 2, pp. 1-30, 2008.

[3] T. Sudarti, "Perbandingan kemampuan penalaran adatif siswa SMP antara yang memperoleh pembelajaran matematika melalui teknik probing dengan metode ekspositori," Skripsi pada Jur. Pendidik. Mat. (tidak diterbitkan). Bandung UPI, 2008.

[4] A. Sardiman, "M. 2014," Interak. Motiv. Belajar Mengajar.

[5] A. A. Saefudin and M. Solahudin, "Menuju Manusia Merdeka Ki Hadjar Dewantara." Yogyakarta: Leutika, 2009.

[6] N. Sudjana, Belajar dan Faktor-faktor yang Mempengaruhinya. 2010.

[7] A. Suharsimi, "Prosedur penelitian suatu pendekatan praktik," Jakarta: Rineka Cipta, 2006.

[8] M. N. Purwanto, Prinsip-prinsip dan teknik evaluasi pengajaran. Remaja Rosdakarya, 2000.

[9] D. Mardalis, Metode penelitian: suatu pendekatan proposal. Bumi Aksara, 1995. 